\title{
Treatment of Slaughterhouse Waste Water Mixed with Serum from Lacteal Industry of Extremadura in Spain to Produce Clean Energy
}

\author{
A. C. Marcos ${ }^{1, *}$, A. Al-Kassir ${ }^{1}$, Francisco Cuadros ${ }^{1}$ and Talal Yusaf ${ }^{2}$ \\ 1 School of Industrial Engineering, University of Extremadura, Avda. de Elvas s/n, 06006 Badajoz, Spain; \\ aawf@unex.es (A.A.-K.); cuadros1@unex.es (F.C.) \\ 2 School of Mechanical and Electrical Engineering, The University of Southern Queensland, Toowoomba 4350, \\ QLD, Australia; talal.yusaf@usq.edu.au \\ * Correspondence: acmarcos@unex.es; Tel.: +34-924-289-600 (ext. 86516)
}

Academic Editor: Xidong Wang

Received: 3 April 2017; Accepted: 24 May 2017; Published: 31 May 2017

\begin{abstract}
The problem of slaughterhouse waste water can be resolved by mixing it with serum from lacteal industry to produce a biogas. The effect of serum addition on the anaerobic co-digestion of solid and liquid slaughterhouse waste has been studied. The experimental device consisted of a continuous digester by recirculation of biogas produced in the anaerobic digestion. The input effluent was a mixture of slaughterhouse waste from Badajoz city (Spain) and animal serum in a proportion of $20 \%$. The anaerobic digestion was developed in a complete mixing continuous digester with a capacity of $6.2 \mathrm{~L}$ at $37^{\circ} \mathrm{C}$ and a feed rate of $350 \mathrm{~mL} /$ day. From the results obtained for the co-digestion of the feeding effluent of the slaughterhouse waste, without and with serum added, in the same operating conditions, comparative data about the biological depuration and biogas production have been obtained. A $10 \mathrm{~L}$ biogas production was obtained with the slaughterhouse waste and $18 \mathrm{~L}$ with the slaughterhouse waste with serum added. In conclusion, the highest energetic yield $(97.52 \%$ higher) was obtained in the second case, due to the positive action of catalytic enzymes present in the animal serum.
\end{abstract}

Keywords: slaughterhouse waste water; treatment; anaerobic biodigestion; lacteal serum

\section{Introduction}

From the 1960s, the rise of industries and demographic growth have seriously affected our water and air reserves. Since then, we have begun to contemplate our environment as something very delicate that we have to preserve, because if we do not, irreversible alterations could result. In fact, the European Union, for many years, has been seriously legislating in an effort to deal with this problem.

With this demographic and industrial growth and the agglomeration of the population in large cities, the generation of agro-industrial wastes has been rising to such alarming levels that the public has become sensitized to the problems caused by this waste if it is not properly managed. Until a few years ago, the waste generated by the small populations and the few industries that existed posed no great problem, since nature itself was able to recycle it into the environment. Today, however, the generation of waste biomass is so abundant and so localized that there is insufficient capacity for its natural degradation, and various treatment techniques have to be applied [1-4].

One of the most polluting food industries is the meat industry. In general, there are three main points of waste production: the livestock pens, the slaughterhouse and the area where the dead animals are handled. The most important focus of contamination occurs in the slaughterhouses, where the slaughter, preparation of meat and some elaborations of secondary products take place. In general, the 
slaughterhouse waste is composed of solids (viscera and offal), purines, blood and cleaning water and it contains organic matter, fats, suspended solids, phosphates, nitrates, nitrites and sodium chloride. The average composition of their liquid effluent, once separated from the voluminous solids, is as follows: total solids $4000 \mathrm{mg} \mathrm{L}^{-1}$, volatile solids $2000 \mathrm{mg} \mathrm{L}^{-1}$, chemical oxygen demand (COD) $2500 \mathrm{mg} \mathrm{L}^{-1}$, 5-day biochemical oxygen demand (BOD 5$) 1000 \mathrm{mg} \mathrm{L}^{-1}$, and nitrogen $250 \mathrm{mg} \mathrm{L}^{-1}$ [2,5].

Slaughterhouses use a large volume of hot water and steam to clean and sterilize the dead carcasses. The aqueous waste from this process, along with the blood, is often downloaded untreated into the municipal sewerage systems or, in many cases, directly over open drains or, worse, over surface water currents. Sometimes, the solid waste is removed by burying or incineration. In the event of burying, the final result is generally the same, because the organic components are filtered into underground systems.

Slaughterhouse effluent has the additional problem of its great variability in composition and concentration, not only from one day to another, but even over the course of a single day according to the operations being carried out at any given time [2].

The meat processing industry uses $24 \%$ of the total freshwater consumed by the food and beverage industry and up to $29 \%$ of that consumed by the agricultural sector worldwide $[1,6,7]$.

Anaerobic digestion is the preferred biological treatment that is applied in slaughterhouse wastewater treatment due to its effectiveness in treating high strength wastewater $[1,8]$.

Although anaerobic treatment possesses great advantages, it hardly produces effluents that comply with current discharge limits and standards. Generally speaking, although anaerobic treatment is an efficient process, the slaughterhouse wastewater organic strength makes it difficult to achieve complete stabilization of the organic compounds [1,9].

The dairy industries, which produce a derivative highly polluting whey or dairy serum, are also among the food industries generating the highest quantity of waste. Dairy serum is defined as a milk fraction, of any species, that does not precipitate because of the action of rennet or because of the acids during the cheese-making process. The main contributors of organic load to these effluents are carbohydrates, proteins and fats originating from the milk [10-12].

The polluting power of dairy serum is very high and, the previous treatment with natural and conventional treatment plants does not fulfill its function, because of the wealth of organic materials carried in lactic sera. The proteins and the lactose become contaminants when the liquid is discharged into the environment without any type of treatment, because the load of organic matter that it contains allows the reproduction of microorganisms.

The dairy wastewaters can be partly reused [13] or treated. Biological processes are usually preferred to treat dairy wastewaters like treatment in ponds, activated sludge plants and anaerobic treatment [12].

The most common purification methods used for the treatment of the discharge liquids produced by the meat and dairy industries, the anaerobic treatments, are insufficient and have important consequences that have been little studied with regard to microbial flora dragging. The problem is when these effluents, poorly cleared and with large biological contributions, are discharged into public waterways, due to unawareness of their impact on health.

The anaerobic digestion process is an imperative tool for the production of clean energy sources, such as hydrogen and methane [12]. Liquids produced by the meat and dairy industries can be processed with anaerobic digestion to produce biogas that can be used to generate heat or electricity. The biogas can be used in a cogeneration system or used for biomethane production which in turn can be sent to national natural gas network or used as a biocombustible fuel in the automotive sector $[14,15]$. There are several studies on the optimization of this process to obtain biogas from slaughterhouse waste [16-18] to solve this problem.

In this work, the influence of the addition of animal dairy serum on the anaerobic codigestion of solid and liquid waste from the municipal slaughterhouse of Badajoz has been studied. From the results of the codigestion of the effluent of solids (viscera and offal), purines, blood and cleaning 
water mixed with serum and without serum, in the same conditions of operation, comparative data of biological depuration and the production of biogas has been obtained. This would solve the problem of whey leftovers in the milk industry and at the same time optimize the production of biogas in slaughterhouses.

\section{Serum and Waste from Dairy and Meat Industry and Their Potential Environmental Pollution}

Serum is from 100 to 200 times more polluting than sewage water, and most municipal treatment plants cannot treat it suitably. Dumping serum into rivers is impossible because it removes oxygen from the water, preventing the life of aquatic fauna. Burying serum in wasteland or gravel pits is not usually convenient because of its filtration into water supplies.

In 2014, cheese production in Spain, according to European Union estimates, was 387,700 tons [19] as shown in Table 1.

Table 1. Lactic serum production [19].

\begin{tabular}{cccc}
\hline Product & $\begin{array}{c}\text { 2012 Production } \\
\text { (in 1000 TM) }\end{array}$ & $\begin{array}{c}\text { 2013 Production } \\
\text { (in 1000 TM) }\end{array}$ & $\begin{array}{c}\text { 2014 Production } \\
\text { (in 1000 TM) }\end{array}$ \\
\hline Cheese & 322.6 & 361.9 & 387.7 \\
Butter & 36.7 & 35.5 & 39.8 \\
Added lactic serum & 1509.9 & 1794.8 & 1798.7 \\
Total lactic serum & 2903.4 & 3257.1 & 3489.3 \\
\hline
\end{tabular}

During the cheese-making process, lactoserum is the liquid fraction of milk obtained after the precipitation and recovery of caseine [20] (Table 2).

Table 2. Lactic serum chemical composition [20].

\begin{tabular}{cc}
\hline Parameter & Sample \\
\hline COD $\left(\mathrm{g} \mathrm{L}^{-1}\right)$ & 68.6 \\
$\operatorname{BOD}_{5}\left(\mathrm{~g} \mathrm{~L}^{-1}\right)$ & 37.71 \\
$\mathrm{SST}\left(\mathrm{g} \mathrm{L}^{-1}\right)$ & 1.35 \\
Lactose $\left(\mathrm{g} \mathrm{L}^{-1}\right)$ & 45.9 \\
Proteins $\left(\mathrm{g} \mathrm{L}^{-1}\right)$ & 2.71 \\
$\mathrm{pH}$ & 4.9 \\
$\mathrm{NTK}\left(\mathrm{g} \mathrm{L}^{-1}\right)$ & 1.12 \\
FT $\left(\mathrm{g} \mathrm{L}^{-1}\right)$ & $0.5 \times 10^{-3}$ \\
\hline
\end{tabular}

This subproduct is around $85-95 \%$ of the total volume of the milk used and it is estimated to contain $55 \%$ of nutrient [21]. The production established is around $9 \mathrm{~L} / \mathrm{kg}$ of the produced cheese [21] and it is therefore considered the main subproduct of the cheese industry. Accordingly, the quantity of serum produced in Spain could be approximately 3,489,300,000 L/year (Table 1), of which $1,798,700,000 \mathrm{~L} /$ year have been used in the production of different dairy products.

From the other 1,690,600,000 L/year, a dairy serum production of 4,631,780 L/day can be produced, with a polluting power similar to a population of 15-19 million habitants per day [22,23].

The biological oxygen demand (BOD) of lactic serum varies between 20,000 and 50,000 $\mathrm{mg}$ of $\mathrm{O}_{2}$ / $\mathrm{L}$ [24]. In consequence, around $0.25-0.30 \mathrm{~L}$ of serum are equivalent to the black waters produced by a person per day PE (population equivalent) [23,24].

According to the Ministry of Agriculture, Fishing and Food of Spain [19], the volume of national serum production has increased considerably (Table 1) because of the increase of cheese and butter production. It is interesting to note that an average cheese industry that produces $400,000 \mathrm{~L}$ of unpurified serum daily is producing daily pollution similar to a population of $1,250,000$ [23,24]. 
On the other hand, in the meat industry the waste generated is so abundant that self-degradation is insufficient, and different treatment techniques must be applied. According to the agriculture macromagnitudes for 2014 of the Ministry of Agriculture, Fishing and Food of Spain [19], the census of animals per species is summarized in Table 3.

Table 3. Animals census by species, 2014 [19].

\begin{tabular}{ccccc}
\hline Animal & Badajoz & Cáceres & Extremadura & Spain \\
\hline Bovine & 281,694 & 504,022 & 785,716 & $6,078,733$ \\
Ovine & $1,976,013$ & $1,065,321$ & $3,041,334$ & $15,431,804$ \\
Caprine & 112,534 & 135,173 & 247,707 & $2,704,229$ \\
Porcine & 809,200 & 119,529 & 928,729 & $26,567,578$ \\
\hline
\end{tabular}

At regional level, the number of slaughtered heads in Extremadura during the period between 2000 and 2014 is shown in Table 4, and this would lead to great environmental pollution, depending on the waste generated. Table 5 reports the residues generated per sacrificed animal [24].

Table 4. Number of sacrificed animals in 2011, 2012, 2013 and 2014 in Extremadura (Spain) [1].

\begin{tabular}{ccccc}
\hline $\begin{array}{c}\text { Sacrificed } \\
\text { Animals }\end{array}$ & $\begin{array}{c}\text { Number of } \\
\text { Animals 2011 }\end{array}$ & $\begin{array}{c}\text { Number of } \\
\text { Animals 2012 }\end{array}$ & $\begin{array}{c}\text { Number of } \\
\text { Animals 2013 }\end{array}$ & $\begin{array}{c}\text { Number of } \\
\text { Animals 2014 }\end{array}$ \\
\hline Bovine & 81,178 & 74,373 & 80,298 & 88,943 \\
Porcine & 608,496 & 524,838 & 429,295 & 489,281 \\
Ovine & 300,209 & 276,622 & 276,253 & 275,619 \\
Caprine & 34,103 & 22,504 & 23,644 & 22,505 \\
Total & $1,023,986$ & 898,337 & 809,490 & 876,348 \\
\hline
\end{tabular}

Table 5. Estimate of the quantity of offal generated per carcass [25].

\begin{tabular}{cccccccc}
\hline $\begin{array}{c}\text { Type of } \\
\text { Animal }\end{array}$ & $\begin{array}{c}\text { Gross } \\
\text { Weight (kg) }\end{array}$ & $\begin{array}{c}\text { Carcass } \\
\text { Weight } \mathbf{( k g )}\end{array}$ & $\begin{array}{c}\text { Total by-Products } \\
\mathbf{( k g )}\end{array}$ & $\begin{array}{c}\text { Blood } \\
(\mathbf{L})\end{array}$ & $\begin{array}{c}\text { Fat } \\
\mathbf{( k g})\end{array}$ & $\begin{array}{c}\text { Intestines } \\
(\mathbf{k g})\end{array}$ & $\begin{array}{c}\text { Other } \\
\text { by-Products (kg) }\end{array}$ \\
\hline Bovine & 540 & 300 & 240 & 39.4 & 32.6 & 26.6 & 141.4 \\
Porcine & 160 & 115 & 45 & 11.2 & 1.7 & 1.3 & 30.8 \\
Ovine & 20 & 11 & 9 & 1.4 & 0.5 & 1.9 & 5.2 \\
Caprine & 12 & 6 & 6 & 0.8 & 0.3 & 1 & 3.9 \\
\hline
\end{tabular}

The pollution generated by products obtained from the slaughter of the different species of livestock can be estimated in terms of BOD (biological oxygen demand). Hence, expressing the values of BOD in terms of population equivalent, the pollution generated by the slaughterhouses of Extremadura Community for 2014 would be approximately 181,404 PE (population equivalent) (Table 6). Population equivalent is the number expressing the ratio of the of the total pollution load produced during $24 \mathrm{~h}$ and the individual one produced by one person in the same time. For this work it is assumed this number equals $60 \mathrm{~g}$ of BOD per $24 \mathrm{~h}$.

Table 6. Pollution expressed in population equivalents (PE) in 2014.

\begin{tabular}{ccccc}
\hline $\begin{array}{c}\text { TYPE OF } \\
\text { ANIMAL }\end{array}$ & $\begin{array}{c}\text { Animals } \\
\text { Butchered in } \mathbf{2 0 1 4}\end{array}$ & $\begin{array}{c}\text { BOD }_{\mathbf{5}} \\
\left(\mathbf{g ~ L}^{-\mathbf{1}}\right) / \text { Carcass }\end{array}$ & $\begin{array}{c}\text { Contamination } \\
\text { in PE }\end{array}$ & $\begin{array}{c}\text { Total Contamination } \\
\text { (PE) in the Region of } \\
\text { Extremadura }\end{array}$ \\
\hline Bovine & 88,943 & 12.42 & 0.2070 & 18,411 \\
Porcine & 489,281 & 12.42 & 0.2070 & 101,281 \\
Ovine & 275,619 & 12.42 & 0.2070 & 57,053 \\
Caprine & 22,505 & 12.42 & 0.2070 & 4659 \\
& & & Total & 181,404 \\
\hline
\end{tabular}




\section{Materials and Methods}

\subsection{Experimental Assembly}

The experimental CSTR-type digester (Continuous Stirred Tank Reactor) consisted of a 6 L tank mixed by means of forced convection of methane produced in the anaerobic digestion (Figures 1 and 2). The digester was primed with a suitable volume of anaerobic sludge from the Badajoz sewage treatment plant. The components of the digester were as follows:

1. Primary digester/reactor (stirred tank)

2. Secondary digester/degasifier

3. Control system

4. Pumping equipment

5. Heating system

6. Substrate tank

7. Feed stream

8. Gas stream

9. Slurry stream

10. Product slurry stream

11. Sampling

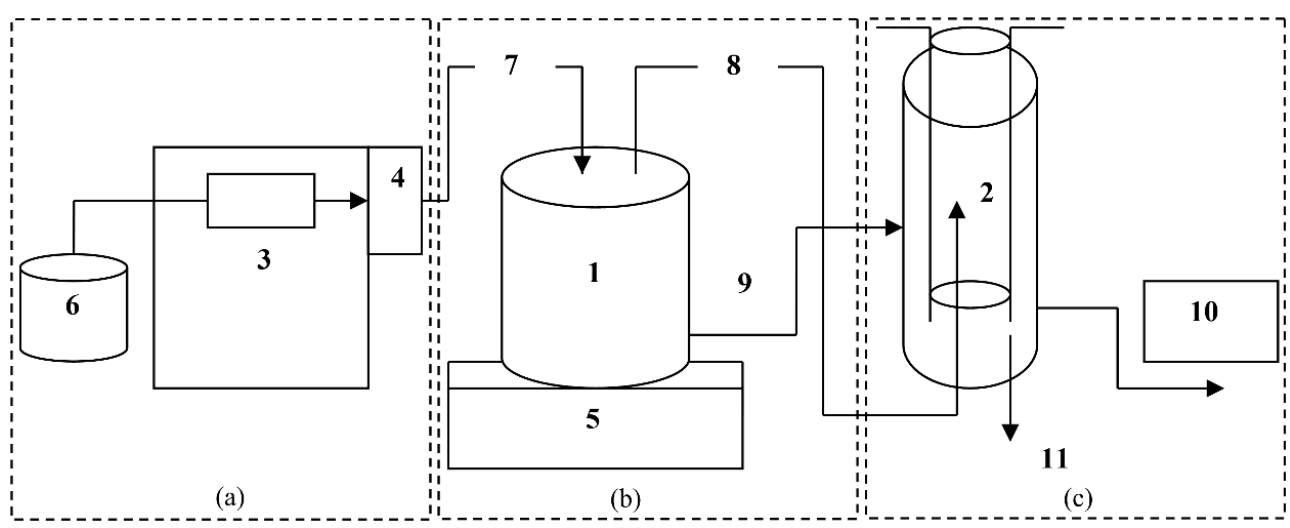

Figure 1. Schematic diagram of a continuous anaerobic digestion pilot plant.
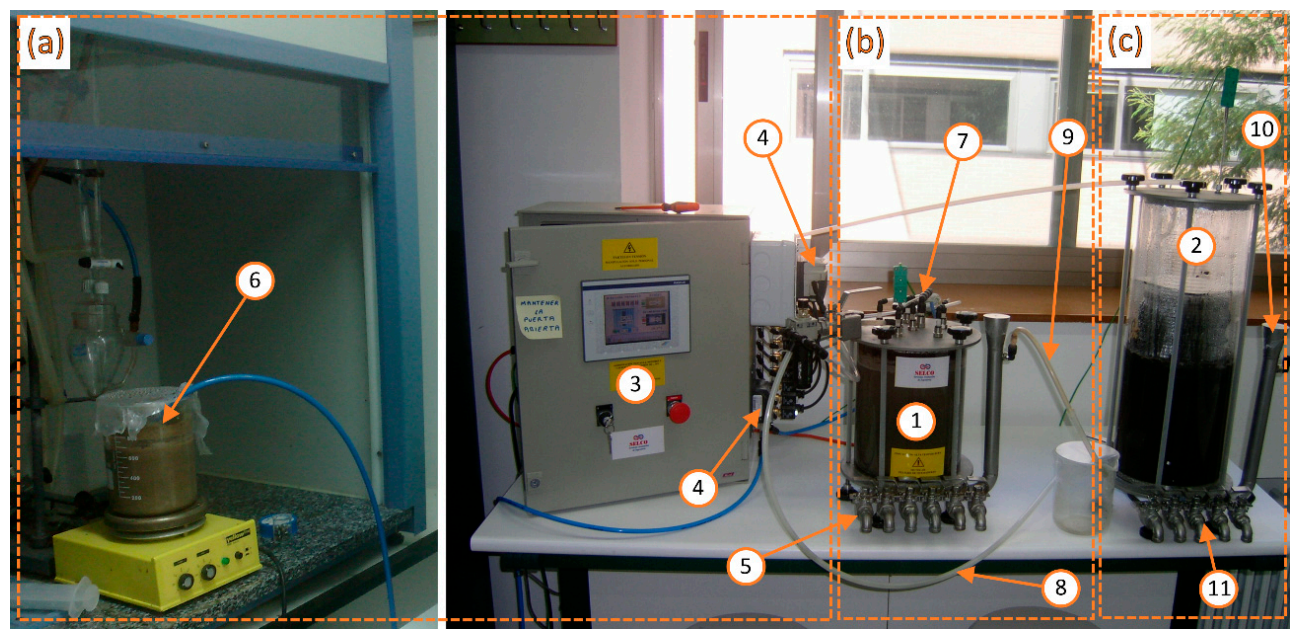

Figure 2. Continuous digester. 
Three groups have been formed to describe the configuration of the experiment:

(a) Substrate tank, control system and pumping equipment

(b) Primer digester, heating system and feed and gas streams

(c) Secondary digester, slurry stream, product slurry stream and sampling

\subsubsection{Substrate Tank (6), Control System (3) and Pumping Equipment (4): (a)}

The substrate storage tank (6) has a capacity of $3 \mathrm{~L}$. It is a hermetic glass cylinder, with a graduated scale to monitor the flow rate. It is equipped with a mechanical stirrer to maintain the homogeneity of the substrate before this is fed into the primary digester.

The control system (3) comprises the elements that control the influent and digester temperature and mixing systems. It consists of a locker, a control element, and electrical elements.

The parameters controlled in the control system are:

- Primary digester temperature

- Average flow of influent by means of electronic variation of speed and possibility of acting on the useful operating time

- $\quad$ Alternating timing between valves

A peristaltic pump (4) draws the gas off from the digester and, under the control of a programmable automatic device connected to electrical valves and a collector, recirculates the gas to mix the slurry in the tank or leads the surplus gas off to the secondary digester or to the bell jar for storage.

\subsubsection{Primary Digester (1), Heating System (5) and Feed and Gas Streams (7) (8): (b)}

The primary digester (1) is of the CSTR type, heated and with complete mixing. Its volume is 6.2 L. Given the scale, and that the equipment is for indoor use, there is no problem in maintaining the temperature by means of ceramic resistors installed at the bottom of the digester, fed with a security current of $24 \mathrm{~V}$.

The influent flow rate to the digester is controlled by a peristaltic type dosing pump at either a constant or a programmed rate. Mixing is by means of re-compressing the biogas that is produced in the digestion process. Two major advantages of this arrangement are the ease of cleaning the systems, it being unnecessary to halt or unmount the components of the digester, and the scalability of the system to digesters of different sizes.

The amount of biomass in the digester is maintained by means of an overflow. Surplus biomass can be led off to a secondary digester or to an appropriate deposit.

The digester is heated by a novel system of PTC-type ceramic cartridges (5). These cartridges have a very smooth and uniform heating characteristic. They also have a safety system that stops the liquid exceeding $80^{\circ} \mathrm{C}$ in the case of inappropriate handling (a situation that would otherwise cause the destruction of the biomass, among other consequences).

The substrate is fed into the digester by means of a peristaltic dosing pump (7). This is under the control of the automatic device which is programmed to dose the daily amount of influent by timing and flow rates. The substrate enters the digester through a neoprene tube connected to the pump.

One part of the biogas produced in the digester is pumped back into the digester (8), and another part is stored in the bell jar or secondary digester (2). All the associated plumbing is PVC.

\subsubsection{Secondary Digester (2), Slurry Stream (9), Product Slurry Stream (10) and Sampling (11): (c)}

The design of the secondary digester (2) as a $6 \mathrm{~L}$ capacity movable rigid bell jar presents the following advantages:

Ease of monitoring - the volume of biogas produced by the movable bell which allows a visual reading of the accumulated biogas. Safety-the liquid content forms a barrier that is impermeable to 
the biogas. Surplus biogas or biogas produced within the bell jar is completely sealed off, and can be led off to a secure place (burner, a Tedlar gas sampling bag, or simply to the exterior). Fire risks and bad odours are thus totally obviated.

There is the possibility of secondary digestion in which the gasometer can operate as a secondary digester, with a second accumulation of the effluent (without temperature control). It can also operate without secondary digestion by being filled with clean water. In the secondary digester mode, it has a purging system for sampling the settled sludge, and an overflow system that is analogous to that of the primary digester for control of the level.

A slurry stream (9) can be set up between the overflows of the primary and secondary digesters using PVC tubing.

The degraded slurry from both primary and secondary digesters is led off through the installed overflows (10).

Taps (11) on the lower part of the primary and of the secondary digesters allow samples to be taken.

The optimal composition of the substrate that the biodigester would allow without inhibition of the process was, according to our experimental data, $84 \%$ wastewater, $10 \%$ purines, and $6 \%$ solids [26].

\subsection{Characterization of Influent}

To perform the experiments of anaerobic digestion, it is essential to know, upon implementation of the biodigester:

(i) (The optimum percentage of the composition of the feed stream which is limited in terms of the $\%$ maximum of solids that the biodigester can admit without being inhibited, and it has been determined experimentally:

- For experiment 1 , codigestion of slaughterhouse waste [26]:

- $\quad 6 \%$ solids (viscera and offal)

- $\quad 10 \%$ purines

- $\quad 84 \%$ blood + cleaning water

- For experiment 2, codigestion of slaughterhouse waste mixed with animal serum:

- $\quad 80 \%$ Slaughterhouse waste:

- $\quad 6 \%$ solids (viscera and offal)

- $\quad 10 \%$ purines

- $\quad 84 \%$ blood + cleaning water

- $\quad 20 \%$ Dairy serum

(ii) The operating conditions selected to obtain the maximum treatment and biogas production, which have also been determined in the laboratory:

- Feeding rate: $350 \mathrm{~mL} /$ day [8].

- $\quad$ Digester temperature: mesophilic regimen $37^{\circ} \mathrm{C}$.

Once the composition of each preset input current was fixed, we proceeded to its physico-chemical characterization, determining parameters such as $\mathrm{pH}, \mathrm{COD}, \mathrm{BOD}_{5}, \mathrm{VSS}$, nitrogen, phosphates, etc. (determined according to the methodology obtained from the literature $[27,28]$ ), which are indicative of the contamination present in the sample.

According to experiment 1 (codigestion of slaughterhouse waste, Table 7), approximately similar values are obtained as for the input effluent of experiment 2 (codigestion of slaughterhouse waste + animal serum, Table 7), except for the case of chemical and biochemical oxygen demand and volatile acidity. 
Table 7. Characterization of the influent substrate in experiments.

\begin{tabular}{ccccccccc}
\hline Experiment & $\mathrm{pH}$ & $\begin{array}{c}\mathrm{COD}_{\text {total }} \\
(\mathrm{mg} / \mathrm{L})\end{array}$ & $\begin{array}{c}\mathrm{BOD}_{\mathbf{5}} \\
(\mathrm{mg} / \mathrm{L})\end{array}$ & $\begin{array}{c}\text { VSS } \\
(\mathrm{g} / \mathrm{L})\end{array}$ & $\begin{array}{c}\text { Total } \\
\text { Nitrogen }(\mathrm{g} / \mathrm{L})\end{array}$ & $\begin{array}{c}\text { Volatile Acid }(\mathrm{g} \\
\text { Acetic Acid/L) }\end{array}$ & $\begin{array}{c}\text { Alkalinity } \\
(\mathrm{gCaCO} / \mathrm{L})\end{array}$ & $\begin{array}{c}\text { Phosphates } \\
(\mathrm{g} / \mathrm{L})\end{array}$ \\
\hline $\mathbf{1}$ & 6.51 & 41,500 & 12,420 & 8.56 & 1.27 & 0.95 & 1.1 & 0.19 \\
$\mathbf{2}$ & 6.64 & 50,000 & 17,450 & 8.25 & 1.1 & 1.9 & 1 & 0.19 \\
\hline
\end{tabular}

This difference is explained by the addition of animal serum at a proportion of $20 \%$ in experiment 2 : the increase of the COD is due to the richness in organic matter in the whey.

Once the operating conditions and inflows are known, various codigestions are performed in the digester (Figure 1), obtaining the final values once the steady state is reached of the main parameters of each experiment, shown in Table 8.

Table 8. Final values of the main parameters and the characteristic parameters for the different experiments, where $\mathrm{Q}$ is the flow rate $\left(\mathrm{mL} /\right.$ day), $\mathrm{HRT}$ is the hydraulic residence time (day), $\mathrm{COD}_{\mathrm{f}}$ is the chemical oxygen demand (mg/L), $\mathrm{V}_{\text {Biogas }}$ is the volume of biogas $(\mathrm{mL} / \mathrm{h}), \mathrm{N}_{\text {Total }}$ is the total nitrogen $(\mathrm{g} / \mathrm{L})$, TC total carbon $(\mathrm{mg} / \mathrm{L}), \mathrm{BOD}_{5}$ is biological oxygen demand $\left(\mathrm{mg} \mathrm{L}^{-1}\right)$, Acid is the acidity $\left(\mathrm{g} \mathrm{L}^{-1}\right)$, Alkalinity $\left(\mathrm{g} \mathrm{L}^{-1}\right)$, SSV is volatile suspended solids $\left(\mathrm{g} \mathrm{L}^{-1}\right)$, Phosphates $\left(\mathrm{g} \mathrm{L}^{-1}\right)$.

\begin{tabular}{|c|c|c|c|c|c|c|}
\hline $\begin{array}{c}\text { Main } \\
\text { Parameters }\end{array}$ & Q (mL/Day) & HRT (Day) & $\underset{\left(\mathrm{mg} \mathrm{L}^{-1}\right)}{\mathrm{COD}_{\mathrm{f}}}$ & $\begin{array}{l}V_{\text {Biogas }} \\
(\mathrm{mL} / \mathrm{h})\end{array}$ & $\begin{array}{l}\mathrm{N}_{\text {Total }} \\
\left(\mathrm{g} \mathrm{L}^{-1}\right)\end{array}$ & $\begin{array}{c}\mathrm{CT} \\
\left(\mathrm{mg} \mathrm{L}^{-1}\right)\end{array}$ \\
\hline Experiment 1 & 350 & 18 & 10,250 & 450 & 1.03 & 840 \\
\hline Experiment 2 & 350 & 18 & 15,375 & 750 & 0.51 & 829 \\
\hline $\begin{array}{c}\text { Characteristic } \\
\text { Parameters }\end{array}$ & $\begin{array}{c}\mathrm{BOD}_{5} \\
\left(\mathrm{mg} \mathrm{L}^{-1}\right)\end{array}$ & Acid $\left(\mathrm{g} \mathrm{L}^{-1}\right)$ & $\begin{array}{l}\text { Alkalinity } \\
\left(\mathrm{g} \mathrm{L}^{-1}\right)\end{array}$ & $\begin{array}{c}\text { SSV } \\
\left(\mathrm{g} \mathrm{L}^{-1}\right)\end{array}$ & $\begin{array}{l}\text { Phosphates } \\
\qquad\left(\mathrm{g} \mathrm{L}^{-1}\right)\end{array}$ & \\
\hline Experiment 1 & 8,180 & 0.73 & 6.5 & 2.86 & 1.33 & \\
\hline Experiment 2 & 13,575 & 3.15 & 8.9 & 2.62 & 1.02 & \\
\hline
\end{tabular}

For the digestion of slaughterhouse effluents in experiment 1 , further refinement of the organic load occurs for the same hydraulic residence time (HRT), which can be seen through the final COD values reflected in Table 8 . However, with respect to the performance of biogas production, experiment 2, corresponding to the digestion of slaughterhouse waste and animal serum, generates an average flow of $750 \mathrm{~mL} / \mathrm{h}$ of biogas (Table 8 ), a value much higher than that for experiment 1 . Another parameter indicative of the pollutant load of the effluent outlet is the nitrogen present in the sample, whose values are very restricted according to current regulations on waste disposal. Comparing the results of the determination of total nitrogen in both experiments, it can be concluded that in the treatment with lactic serum a further degradation of nitrogen is produced, in contrast to the accumulation generated in experiment 1 (Table 8).

There are other parameters whose analysis is essential to understand the behaviour of anaerobic digestion in both experiments. Table 8 records the final values of the characteristic parameters. Taking into account the microbial population in the sample, through the volatile suspended solids (VSS) (Table 8), no major difference is seen between the two experiments, which means that despite the high pollution of the whey load, the bacteria responsible for performing digestion are unaffected, and a higher proportion of serum in the effluent input is tolerated.

On the other hand, the volatile acidity (Table 8), a parameter indicative of process stability and potential inhibition phenomena, reaches much higher values in experiment 2 than those obtained in experiment 1, in accordance with specialized literature [26], reaching concentrations near inhibition. Despite the excessive acidity of the effluent outlet (explained by the acidity of the animal serum) (Table 7), the microbial population appears to be unaffected, as discussed in the previous section.

The collected values for the main parameters and characteristics can be compared in an attempt to determine which of the two experiments is more profitable. 


\subsection{Methods}

In general, industrial wastewater lacks suitable microorganisms to perform biodigestion, so it is necessary to have an acclimated inoculum [29]. In our case, as the starting inoculums in the biodigestor we use a mixture of anaerobic sludge from an urban sewage treatment plant and cow manure rich in methanogenic bacteria.

First of all, and in all experiments, it is necessary to acclimate this anaerobic population to the degradation of the slaughterhouse residue and added serum. For this purpose, increasing volumetric loads of residues were added, for one month, until a steady-state condition was reached, that is to say, a constant in the production of methane. Next, the feed of liquid waste was started.

To prepare the samples for the different experiments that we carried out, account was taken of the average number of heads from the slaughterhouse of Badajoz, as well as the species, sacrificed during the year (Table 4). The experimentation carried out in the municipal slaughterhouse of Badajoz allows us to know the average amount of residues which is generated by the slaughter and later processing in the slaughterhouse, per head of each animal species. These values are shown in Table 5 .

The experiments, carried out with a feeding of $350 \mathrm{~mL} \mathrm{day}^{-1}$, were developed for different porcine, bovine, ovine and caprine cases. The results obtained enabled a comparison of the yield achieved in terms of degraded COD and methane production for different bloods, following the evolution of parameters such as $\mathrm{pH}, \mathrm{COD}, \mathrm{BOD}_{5}, \mathrm{SSV}$, nitrogen, phosphates, etc., through the methodology obtained from the literature $[27,28]$.

The parameters that we studied and controlled for each experiment were: the main parameters of the COD, the volume of methane produced (Table 9) and the characteristic parameters of volatile acidity, alkalinity, $\mathrm{BOD}_{5}, \mathrm{VSS}$, nitrogen and phosphates (Table 10), for the same initial load of feed of the porcine, ovine and bovine, and caprine types investigated in experiment 1 and with $20 \%$ serum added in experiment 2 .

Table 9. Average composition of lactic serum in powder (in $100 \mathrm{~g}$ of substance).

\begin{tabular}{cccc}
\hline & Bovine & Ovine & Caprine \\
\hline Humidity & 5 & 5 & 5 \\
Protein & $11-14$ & $18-20$ & $14-16$ \\
Lactose & $75-80$ & $67-69$ & $63-66$ \\
Mineral salts & $7-9$ & $8-10$ & $11-13$ \\
Lactic acid & $1.4-2.0$ & $1.5-2.0$ & $1.5-2.0$ \\
\hline
\end{tabular}

Table 10. Parameters of the anaerobic codigestion yield for the different experiments, where $\mathrm{COD}_{\mathrm{f}}$ is the chemical oxygen demand (mg/L), $\mathrm{CH}_{4}$ methane $\mathrm{m}^{3} / \mathrm{kg}$ COD, VSS is volatile solids $\mathrm{kg} / \mathrm{kg}$ COD, SMA specific methanogenic activity.

\begin{tabular}{ccccc}
\hline Experiment & $\mathbf{Q}$ (mL/Day) & $\mathbf{m}^{\mathbf{3}} \mathbf{C H} / \mathbf{k g}$ COD & kg VSS/kg COD & SMA mlCH $/$ gvss Day \\
\hline $\mathbf{1}$ & 350 & 0.500 & 0.092 & 108.17 \\
$\mathbf{2}$ & 350 & 0.822 & 0.075 & 195.86 \\
\hline
\end{tabular}

In all experiments, a $37^{\circ} \mathrm{C}$ constant temperature was maintained, which is considered the most accurate value within the temperature range typical of mesophilic microorganisms, and therefore the most suitable for anaerobic digestion.

\section{Results and Discussion}

To study the advantages of the addition of dairy serum for the anaerobic co-digestion of slaughterhouse waste, all the variables affecting the process should be analyzed, and a comparison between the obtained values has been performed: 
- From the point of view of organic degradation (Table 8) it will be more cost-effective to use a feed stream consisting exclusively of slaughterhouse waste, from which a final product with a smaller $\mathrm{COD}_{\mathrm{f}}$ of $10,250 \mathrm{mg} / \mathrm{L}$ will be obtained. In the case of adding animal serum, a $\mathrm{COD}_{\mathrm{f}}$ of $15,375 \mathrm{mg} / \mathrm{L}$ was obtained, as can be seen in Figure 3.

- $\quad$ On the other hand, according to municipal ordinances, the limit values of discharge into the sewer system for further processing in industrial water treatment [30,31] are around about $1500 \mathrm{mg} / \mathrm{L}$. According to the experiments carried out, the residual COD complies with current regulations, if a separation process (filtration, decantation by gravity, centrifugation ...) is then applied [26]. In the case of experiment 1, the liquid effluent would reach a chemical oxygen demand below the values required. However, for the co-digestion of slaughterhouse waste with serum in experiment 2, direct discharge is not possible without using subsequent purification treatments to reduce the COD effluent output, or producing compostage and converting it into an organic fertilizer.

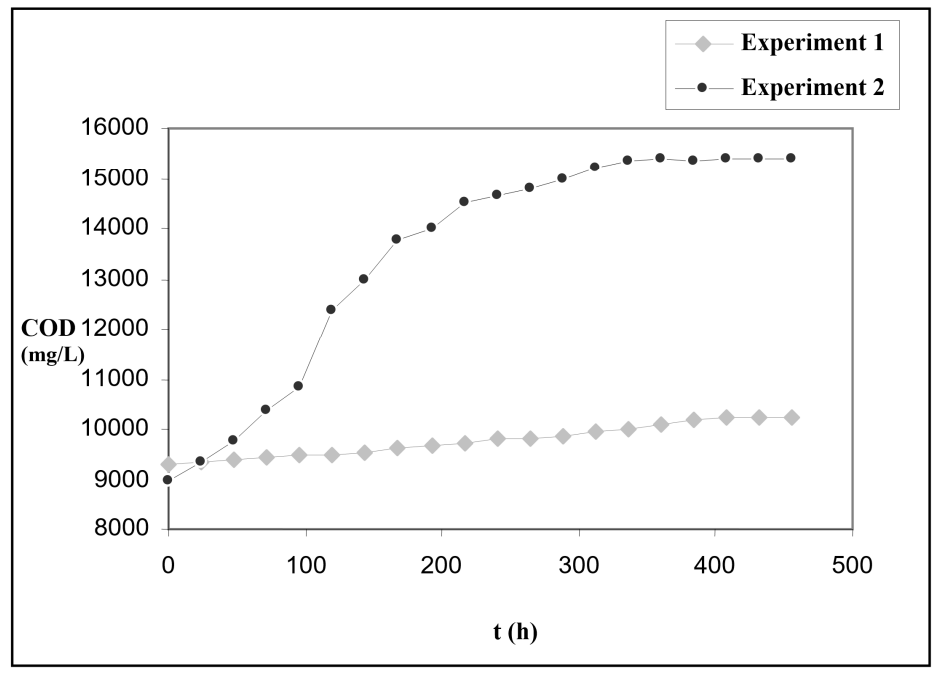

Figure 3. COD evolution.

- From the point of view of the biogas production yield, as shown in Figure 4, after reaching steady state operation, $18 \mathrm{~L}$ for mixing and serum slaughterhouse waste, and about $10 \mathrm{~L}$ for slaughterhouse waste in daily productions are obtained. For the purpose of biogas production, experiment 2 is advantageous.

- $\quad$ To explain the large difference in biogas production by the simple addition of $20 \%$ of animal serum, it is necessary to know the chemical composition of serum (Table 2), which is summarized in Table 9 according to each animal type. The presence of lactose in appreciable quantities in the whey enables metabolization as many microorganisms are employed as substrate. This results in lower molecular mass compounds, as would be the lactic acid, which would be more easily assimilated by other organisms found in the anaerobic sludge.

- Moreover, there are signs of propionic fermentation, which is carried out by the action of bacteria of the Propionibacterium type, fermenting lactic to propionic acid, acetic acid, $\mathrm{CO}_{2}$ and water. 


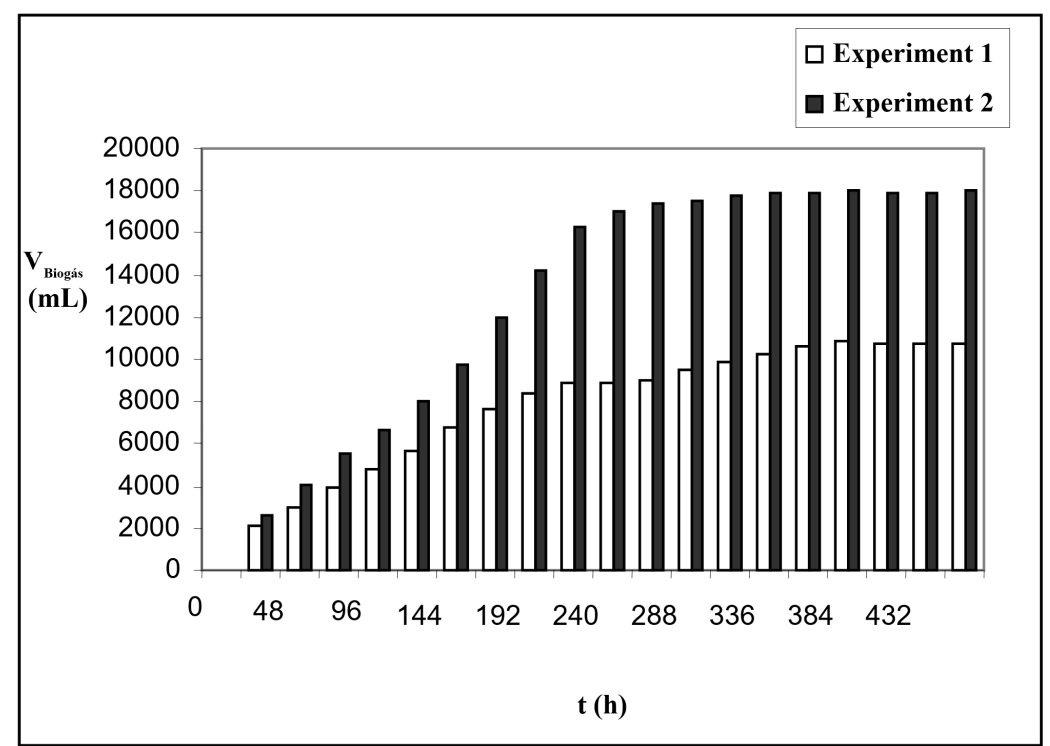

Figure 4. Biogas production.

The given reactions encompass anaerobic digestion [26]:

$$
\begin{gathered}
\mathrm{COD} \rightarrow \mathrm{VFA}_{2}+\mathrm{VFA}_{3}+\mathrm{CO}_{2(\mathrm{~d})}+\mathrm{H}_{2(\mathrm{~g})} \\
\mathrm{VFA}_{2} \rightarrow \mathrm{CO}_{2(\mathrm{~d})}+\mathrm{CH}_{4(\mathrm{~g})} \\
\mathrm{VFA}_{3} \rightarrow \mathrm{CO}_{2(\mathrm{~d})}+\mathrm{VFA}_{2}+\mathrm{H}_{2(\mathrm{~g})}
\end{gathered}
$$

- $\quad$ where COD is the chemical oxygen demand, $\mathrm{VFA}_{2}$, acetic acid and $\mathrm{VFA}_{3}$, propionic acid. These break down the lactic acid into propionic acid and acetic acid, which generates more raw material from which we obtain biogas.

- Therefore, the addition of animal sera in the anaerobic co-digestion of solid and liquid waste slaughterhouse methanogenic phase promotes digestion, which is reflected in a substantial increase in the biogas production. Thus, the whey can be defined as an inexhaustible energy source.

- Other parameters that provide insight into the degree of profitability of each experiment are performance parameters, which provide us with summary information of the results.

- In the literature, the following performance parameters are often used to determine the effectiveness of anaerobic digestion:

$$
\begin{array}{ll}
\text { - } & \mathrm{m}^{3} \mathrm{CH}_{4} / \mathrm{kg} \mathrm{COD} \\
\text { - } & \mathrm{kg} \mathrm{VSS} / \mathrm{kgCOD} \\
\text { - } & \text { SMA: specific methanogenic activity: } \mathrm{mL} \mathrm{CH}_{4} / \mathrm{g}_{\mathrm{VSS}} \text { day }
\end{array}
$$

- $\quad$ If we compare the values obtained for both experiments (Table 10), the logical choice would be the mixture of whey and slaughterhouse waste of experiment 2 , because higher yields than those achieved by the exclusive digestion of slaughterhouse waste are obtained.

- Finally, at the economic level, it is interesting to perform an energy recovery from each experiment to make a final choice.

This evaluation determines the amount of electricity that would be obtained (kWh daily) if we turned all the biogas produced throughout every experiment into electricity through a cogeneration system. 
(a) Yield parameters. Table 10 lists the yield parameters for the two experiments.

Of the two experiments performed, a higher yield was obtained in experiment 2 than in experiment 1 (Table 8).

(b) Energy evaluation. In this subsection, the energy of the biogas produced by an anaerobic digester of slaughterhouse waste with $20 \%$ serum added is evaluated. According to the optimal data described above, for the optimal flow rate of $350 \mathrm{~mL} /$ day, the influent, effluent, and degraded COD values are (Table 7):

$$
\begin{gathered}
\mathrm{COD}_{\text {influent }}=50,000 \mathrm{mg} \mathrm{L}^{-1} \\
\mathrm{COD}_{\text {effluent }}=15,375 \mathrm{mg} \mathrm{L}^{-1}(\mathrm{HRT}=18 \text { days }) \\
\mathrm{COD}_{\text {degraded }}=\mathrm{COD}_{\text {influent }}-\mathrm{COD}_{\text {effluent }}=50,000 \mathrm{mg} \mathrm{L}^{1}-15,375 \mathrm{mg} \mathrm{L}^{-1}=34,625 \mathrm{mg} \mathrm{L}^{-1}
\end{gathered}
$$

The laboratory digester used has a capacity of $6.2 \mathrm{~L}$. The degraded COD from this reactor would be:

$$
34,625 \mathrm{mg} \mathrm{L}^{-1} \times 6.2 \mathrm{~L}=214,675 \mathrm{mg}=0.2147 \mathrm{~kg}
$$

In this experiment the total biogas production was $238 \mathrm{~L}$. Hence,

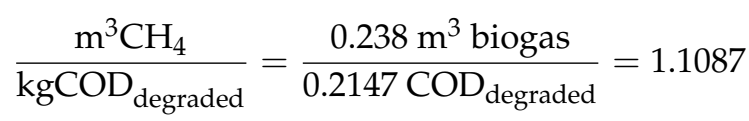

Assuming a methane percentage of $74 \%$,

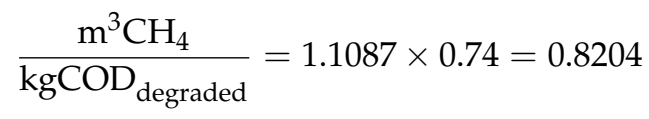

For a flow rate of $0.35 \mathrm{~L} /$ day, with a contaminant load of $50 \mathrm{~g} \mathrm{COD} / \mathrm{L}$, the productivity is:

$$
0.35 \mathrm{~L} \mathrm{day}^{-1} \times 50 \text { g COD. } \mathrm{L}^{-1}=0.0175 \mathrm{~kg} \mathrm{COD} \mathrm{\text {day } ^ { - 1 }}
$$

It can be concluded that $1.1087 \mathrm{~m}^{3} \mathrm{~N}$ of biogas per $\mathrm{kg}$ COD can be obtained, with a concentration of $74 \%$ methane. The daily quantity of biogas that can be generated with the waste from this slaughterhouse is therefore:

$$
1.1087 \mathrm{~m}^{3} \mathrm{~N} / \mathrm{kg} \text { COD } \times 14 \mathrm{~kg} \mathrm{COD} \mathrm{day}{ }^{-1}=0.1940 \mathrm{~m}^{3} \mathrm{~N} \mathrm{day}^{-1}
$$

- $\quad$ Given that the LHV of methane is:

$$
9530 \mathrm{kcal} \times \mathrm{m}^{-3}(\mathrm{n})=11.0814 \mathrm{kWh} \times \mathrm{m}^{-3} \mathrm{~N}^{-1}
$$

and that the biogas obtained has $74 \%$ of methane, the LHV of that biogas will be:

$$
11.0814 \times 0.74=8.20 \mathrm{kWh} \times \mathrm{m}^{-3} \mathrm{~N}^{-1}
$$

This represents a daily energy generation of:

$$
0.1940 \mathrm{~m}^{3} \mathrm{~N} / \text { day } \times 8.20 \mathrm{kWh} / \mathrm{m}^{3} \mathrm{~N}=0.15909 \mathrm{kWh} / \text { day }
$$

- This energy can be used in a boiler to heat fluids of any type, or in an internal combustion engine coupled to an electric generator to produce electrical power. 
- $\quad$ From the results shown in Table 11, it is inevitable to choose experiment 2 as the optimum, achieving an output of $0.2116 \mathrm{kWh} /$ day versus $0.0805 \mathrm{kWh} /$ day obtained for experiment 1 [26]. On the other hand, the energy increment produced in experiment 2 would allow us to perform a second anaerobic digestion. In this way, starting with a COD of $15,375 \mathrm{mg} \mathrm{L}^{-1}$, the COD could be easily reduced to $10,250 \mathrm{mg} \mathrm{L}^{-1}$, and the final residue could be eliminated by the public sewer system $[30,31]$.

Table 11. Energetic evaluation.

\begin{tabular}{ccccccc}
\hline Experiment & $\begin{array}{c}\mathbf{C O D}_{\text {Degradated }} \\
\mathbf{k g}\end{array}$ & $\mathbf{V}_{\text {Biogas }} \mathbf{m}^{\mathbf{3}}$ & $\begin{array}{c}\mathbf{m}^{3} \text { Biogas/kg } \\
\text { DQO }\end{array}$ & $\begin{array}{c}\mathbf{m}^{\mathbf{3}} \mathbf{N} \\
\text { Biogas/Day }\end{array}$ & $\mathbf{k W h} /$ Day & Wh/Day \\
\hline Experiment 1 & 0.19375 & 0.131 & 0.676 & 0.0098 & 0.0805 & 80.5 \\
Experiment 2 & 0.214675 & 0.238 & 1.1087 & 0.0194 & 0.1590 & 159.0 \\
\hline
\end{tabular}

\section{Conclusions}

In this study, we found that it will be more cost-effective to use a feed stream consisting exclusively of slaughterhouse waste with a final product with a smaller $\mathrm{COD}_{\mathrm{f}}$ of $10,250 \mathrm{mg} / \mathrm{L}$ than adding animal serum, where a $\mathrm{COD}_{\mathrm{f}}$ of $15,375 \mathrm{mg} / \mathrm{L}$ is obtained. The biogas production yield has been obtained after reaching steady state operation, with $18 \mathrm{~L}$ of biogas for mixing and serum slaughterhouse waste and about $10 \mathrm{~L}$ of biogas for slaughterhouse waste in daily productions, and here experiment 2 is superior. An energetic evaluation has been performed. It was found that experiment 2 is superior, achieving an output of $0.2116 \mathrm{kWh} /$ day versus the $0.0805 \mathrm{~kW} /$ day obtained in experiment 1 .

Acknowledgments: The authors wish to express their gratitude to the Diputación de Badajoz and the Junta de Extremadura for financial support provided for the development of this project.

Author Contributions: A.C.M. and A.A.-K. conceived and designed the experiments; T.Y. performed the experiments; A.C.M. analyzed the data; F.C. contributed analysis tools; A.C.M. wrote the paper.

Conflicts of Interest: The authors declare no conflict of interest.

\section{Nomenclature}

$\begin{array}{ll}\text { COD } & \text { Chemical oxygen demand } \\ \text { BOD }_{5} & \text { Biological oxygen demand } \\ \text { SMA } & \text { Specific methanogenic activity } \\ \text { E.H. } & \text { Equivalent inhabitant } \\ \text { VS } & \text { Volatile solids } \\ \text { WWTP } & \text { Wastewater treatment plant }\end{array}$

\section{References}

1. Bustillo-Lecompte, C.F.; Mehrvar, M. Slaughterhouse wastewater characteristics, treatment, and management in the meat processing industry: A review on trends and advances. J. Environ. Manag. 2015, 161, 287-302. [CrossRef] [PubMed]

2. Marcos, A.; Al-Kassir, A.; Mohamad, A.A.; Cuadros, F.; López-Rodríguez, F. Combustible gas production (methane) and biodegradation of solid and liquid mixtures of meat industry wastes. Appl. Energy 2010, 87, 1729-1735. [CrossRef]

3. De Gisi, S.; Galasso, M.; De Feo, G. Full-scale treatment of wastewater from a biodiesel fuel production plant with alkali-catalyzed transesterification. Environ. Technol. 2013, 34, 861-870. [CrossRef] [PubMed]

4. De Gisi, S.; Notarnicola, M. Industrial Wastewater TreatmentIn Encyclopedia of Sustainable Technologies, Reference Module in Earth System and Environmental Sciences, 1st ed.; Abraham, M., Ed.; Elsevier Ltd.: Amsterdam, The Netherlands, 2017.

5. Centro de Investigaciones Energéticas, Medioambientales y Tecnológicas (CIEMAT). The Biomass Energy Source and Products for Agriculture and Industry; CIEMAT: Madrid, Spain, 1995. 
6. Mekonnen, M.M.; Hoeskstra, A.Y. A global assessment of the water footprint of farm animal products. Ecosystems 2012, 15, 401-415. [CrossRef]

7. Gerbens-Leenes, P.W.; Mekonnen, M.M.; Hoekstra, A.Y. The water footprint of poultry, pork and beef: A comparative study in different countries and production systems. Water Resour. Ind. 2013, 1, 25-36. [CrossRef]

8. Cao, W.; Mehvar, M. Slaughterhouse wastewater treatment by combined anaerobic baffled reactor and $\mathrm{UV} / \mathrm{H}_{2} \mathrm{O}_{2}$ processes. Chem. Eng. Res. Des. 2011, 89, 1136-1143. [CrossRef]

9. Chan, Y.J.; Chong, M.F.; Law, C.L.; Hassell, D. A review on anaerobic-aerobic treatment of industrial and municipal wastewater. Chem. Eng. J. 2009, 155, 1-18. [CrossRef]

10. Perle, M.; Kimchie, S.; Shelef, G. Somebiochemical aspects of the anaerobic degradation of dairy wastewater. Water Res. 1995, 29, 1549-1554. [CrossRef]

11. Kasapgil, B.; Anderson, G.K.; Ince, O. An investigation into the pretreatment of dairy wastewater prior to aerobic biological treatment. Water Sci. 1994, 29, 205-212.

12. Demirel, B.; Yenigun, O.; Onay, T.T. Anaerobic treatment of dairy wastewaters: A review. Process Biochem. 2005, 40, 2583-2595. [CrossRef]

13. Sharkar, B.; Chakrabarti, P.P.; Vijaykumar, A.; Kale, V. Wastewater treatment in dairy industries-Possibility of reuse. Desalination 2006, 195, 141-152. [CrossRef]

14. Molino, A.; Nanna, F.; Ding, Y.; Bikson, B.; Braccio, G. Biomethane production by anaerobic digestion of organic waste. Fuel 2013, 103, 1003-1009. [CrossRef]

15. Fantin, V.; Giulano, A.; Manfredi, M.; Ottaviano, G. Environmental assessment of electricity generation from an Italian anaerobic digestion plant. Biomass Bioenergy 2015, 83, 422-435. [CrossRef]

16. Molino, A.; Nanna, F.; Villone, A.; Iovane, P.; Tarquini, P.; Migliori, M.; Giordano, G.; Braccio, G. Pressure and time effect over semi-continuous gasification of zootechnical sludge near critical condition of water for green chemicals production. Fuel 2014, 136, 172-176. [CrossRef]

17. Molino, A.; Nanna, F.; Iovane, P. Low pressure biomethane production by anaerobic digestion (AD) for the smart grid injection. Fuel 2015, 154, 319-325. [CrossRef]

18. Ware, A.; Power, N. Biogas from cattle slaughterhouse waste: Energy recovery towards an energy self-sufficient industry in Ireland. Renew. Energy 2016, 97, 541-549. [CrossRef]

19. Ministerio de Agricultura, Pesca y Alimentación, MAPA Anuario de Estadística. Available online: http: / / www.mapama.gob.es (accessed on 20 May 2017).

20. Saddoud, A.; Hassaïri, I.; Sami, S. Anaerobic membrane reactor with phase separation for the treatment of cheese whey. Bioresour. Technol. 2007, 98, 2102-2108. [CrossRef] [PubMed]

21. Remón, J.; Laseca, M.; García, L.; Arauzo, J. Hydrogen production from cheese whey by catalytic steam reforming: Preliminary study using lactose as a model compound. Energy Convers. Manag. 2016, 114, 122-141. [CrossRef]

22. Inda, A. Queso; Organización de los Estados Americanos (OEA): Ciudad de Mexico, Mexico, 2000.

23. Jelen, P. Whey processing-Utilization and productsIn Encyclopedia of Dairy Sciences, 1st ed.; Roginski, H., Ed.; Elsevier: Oxford, UK, 2002; Volume 3, pp. 2739-2745.

24. Valencia, E.; Ramírez, M. La industria de la leche y la contaminación del agua. Cienc. Cult. Elem. 2009, 73, $27-31$.

25. Junta de Extremadura. Consejería de Medio Ambiente y Rural, Políticas Agrarias y Territorio. Available online: http:/ / www.juntaex.es (accessed on 20 May 2017).

26. Marcos, A.; Al-Kassir, A.; López, F.; Cuadros, F.; Brito, P. Environmental treatment of slaughterhouse wastes in a continuously stirred anaerobic reactor: Effect of flow rate variation on biogas production. Fuel Process. Technol. 2012, 103, 178-182. [CrossRef]

27. American Public Health Association (APHA); American Water Works Association (AWWA); Water Pollution Control Federation (WPCF). Standard Methods for the Examination of Water and Wastewater, 15th ed.; American Public Health Association: Washington, DC, USA, 1980.

28. Ramalho, R.S. Tratamiento de Aguas Residuales; Reverté: Barcelona, Spain, 1991.

29. Vrieze, J.; Gildemyn, S.; Vilchez-Vargas, R.; Jáuregui, R.; Pieper, D.H.; Verstraete, W.; Boon, N. Inoculum selection is crucial to ensure operational stability in anaerobic digestion. Appl. Microbiol. Biotechnol. 2015, 99, 189-199. [CrossRef] [PubMed] 
30. Anexo, II. Ordenanzas Municipales de vertidos a la red de alcantarillados públicosIn LEY 10/1993, de 26 de Octubre, Sobre Vertidos Industriales al Sistema Integral de Saneamiento; BOCM 269, de 12-11-1993; C.E BOCM 307, de 27-12-1994; Comunidad de Madrid: Madrid, Spain, 1993.

31. Ordenanza de Vertidos a la Red de Alcantarillado del Excmo, Ayuntamiento de GranadaIn. Ordenanzas de Medio Ambiente; BOP N. 129, 30/5/2000; Ayuntamiento de Granada: Granada, Spain, 2000. 